AKRUAL 1 (2) (2010): 158-170 $e$-ISSN: 2502-6380

\title{
AKRUAL
}

Jurnal Akuntansi

http://fe.unesa.ac.id/ojs/index.php/akrl

\section{ANALISIS KINERJA KEUANGAN DAN PENGARUHNYA TERHADAP HARGA SAHAM (STUDI KASUS PADA PT AQUA GOLDEN MISSISSIPPI, TbK SEBELUM AKUISISI SAHAM DAN SESUDAH AKUISISI SAHAM OLEH DANONE PERIODE TAHUN 1997 - 2007)}

\author{
Entar Sutisman \\ Universitas Jayapura \\ Email: entar_uniyap@yahoo.com \\ Sad Lingga Fitriana \\ Universitas Jayapura \\ Email:- \\ Dianwicaksih Arieftiara \\ Universitas Negeri Surabaya \\ Email: dianwicaksih@gmail.com \\ Artikel diterima: 27 Januari 2010 \\ Revisi terakhir: 1 Maret 2010
}

\begin{abstract}
This research destination is to understand something effect from financial performance to corporate stock price before acquisition and after acquisition. Selected which corporate is PT Aqua Golden Mississippi, Tbk with measuring instrument $z$ - score analysis Taffler model as measuring instrument corporate financial performance and linear regretion to understand something effect from financial performance to stock price with period 1997 - 2007 be based on corporate year after and before acquisition. That indicate from analysis revenue corporate financial performance after and before acquisition significant influence stock price, but just direction relationship which different. This matter because of there are other factor-factor which influence stock price, one of them is corporate drinking water in package stock not likuid in stock exchange. On the contrary, corporate condition after acquisition not significant, this meaning is increase of financial performance not followed with the increasing of corporate stock price
\end{abstract}

Keywords: Financial Performance, Z - Score, Acquisition, Stock Price 


\section{PENDAHULUAN}

Dalam perekonomian modern laporan keuangan sudah merupakan media dalam proses pengambilan keputusan dan menjadi sebuah kebutuhan. Keputusan yang dapat diambil di antaranya adalah keputusan untuk menentukan sebuah investasi, pembelian saham maupun proses go public, dan akuisisi. Laporan keuangan perusahaan yang biasa digunakan diterbitkan secara periodik, tahunan, semester, triwulan, bulanan, bahkan harian, sehingga ditinjau dari sudut pandang manajemen, laporan keuangan merupakan media untuk mengomunikasikan kinerja keuangan perusahaan yang telah dikelola kemudian ditunjukkan kepada pihak-pihak yang berkepentingan, sedangkan ditinjau dari sudut pandang pemakai, informasi laporan keuangan diharapkan dapat digunakan untuk mengambil keputusan yang rasional dalam praktik bisnis yang sehat.

Menurut Adnan dan Kurniasih (2000), perusahaan harus melakukan evaluasi kinerja keuangan dengan menganalisis laporan keuangan. Alat yang digunakan dalam pemeriksaan Adnan dan Kurniasih adalah rasio keuangan. Dari laporan keuangan perusahaan dapat diperoleh informasi tentang posisi keuangan, kinerja perusahaan, aliran kas perusahaan, dan informasi lain yang berkaitan dengan laporan keuangan. Oleh karena itu, analisis laporan keuangan sangat dibutuhkan untuk memahami informasi laporan keuangan. Analisis laporan keuangan tersebut meliputi perhitungan dan interpretasi rasio keuangan. Hasil dari analisis laporan keuangan perusahaan, dapat digunakan oleh pimpinan perusahaan untuk mengetahui keadaan dan perkembangan keuangan perusahaan serta hasil-hasil yang telah dicapai di waktu lampau dan di waktu yang sedang berjalan. Selain itu, dengan melakukan analisis keuangan di waktu lampau, maka dapat diketahui juga kelemahan-kelemahan perusahaan serta hasil-hasilnya yang dianggap telah cukup baik, dan mengetahui potensi kerugian perusahaan serta tingkat kesehatan perusahaan. Tingkat kesehatan perusahaan penting artinya bagi perusahaan untuk meningkatkan efisiensi dalam menjalankan usahanya, sehingga kemampuan untuk memperoleh keuntungan dapat ditingkatkan dan untuk menghindari adanya kerugian.

Sama halnya dengan perusahaan lainnya, PT. Aqua Golden Mississippi, Tbk. juga harus melakukan evaluasi kinerja keuangan yang dilakukan dengan menganalisis laporan keuangan. Dari hasil analisis laporan keuangan yang dilakukan PT. Aqua Golden Mississippi, Tbk., maka dapat diambil suatu keputusan di masa mendatang. PT. Aqua Golden Mississippi, Tbk. merupakan perusahaan pelopor air minum mineral pertama kali di Indonesia yang go public pada 1 Maret 1990. Perusahaan air mineral ini berdiri pada 23 Februari 1973 dan kegiatan fisik perusahaan dimulai pada Agustus 1973, ditandai dengan pembangunan pabrik di kawasan Pondok Ungu, Bekasi, Jawa Barat. Percobaan produksi dilaksanakan pada Agustus 1974 dan produk komersial dimulai sejak 1 Oktober 1974 dengan kapasitas produksi 6 juta liter setahun. Produk pertamanya adalah AQUA botol kaca $950 \mathrm{ml}$ yang kemudian disusul dengan kemasan AQUA galon.

Pada 1974 sampai dengan 1978 merupakan masa-masa sulit, karena masih rendahnya tingkat permintaan masyarakat terhadap produk AQUA. Berbagai upaya 
dan kerja keras dilakukan oleh manajemen perusahaan, salah satunya dengan melakukan diskusi dan simulasi secara langsung di bawah pimpinan Tirto Utomo sebagai pendiri perusahaan. Berbagai analisis dilakukan, termasuk analisis biaya. Manajemen pada akhirnya memutuskan untuk menaikkan harga AQUA dengan konsekuensi akan terjadi penurunan volume penjualan. Diasumsikan bahwa dengan kenaikan harga yang ekstrem, volume penjualan akan turun sebesar 30\%. Dari simulasi tersebut, diambil keputusan untuk menaikkan harga sebesar $133 \%$ agar tercapai titik impas.

Kenaikan harga ini segera diterapkan pada Oktober 1977. Penetapan harga oleh manajemen selama kurun waktu tersebut dinilai terlalu rendah, sehingga berdampak pada image produk dan kepercayaan masyarakat karena pasar yang diambil adalah orang asing dan menengah ke bawah. Kesalahan utama AQUA terletak pada tidak dilakukannya studi banding (benchmark) dengan harga produk sejenis di luar negeri pada masa tersebut. Perbandingan harga produk air mineral di luar negeri diharga sekitar US\$ 1,- per botol dengan nilai tukar berkisar Rp. 350,- per US\$. Sedangkan AQUA menjual Rp. 75,- per botol atau sekitar US\$ 0,20 (dua puluh sen dolar). Setelah menajemen memutuskan untuk melakukan kenaikan harga pada produknya, kepercayaan konsumen perlahan juga mengalami peningkatan. Hal ini dibuktikan dengan mulai dikenalnya produk AQUA di masyarakat, sehingga penjualan dapat ditingkatkan dan akhirnya titik impas berhasil dicapai pada 1978.

Pada 1997, akibat terjadinya krisis moneter, PT. Aqua mencatat pertumbuhan di bawah $30 \%$. Hal itu disebabkan perusahaan hanya menghasilkan laba bersih sebesar Rp 7,8 miliar atau turun sebesar 25\% dibandingkan dengan 1996. Selain itu, pendapatan perusahaan juga turun sebesar 23\% dari Rp 220,8 miliar menjadi Rp 179,4 miliar pada 1996 (Financial Highlight Aqua, 1997). Oleh karena itulah, PT. Aqua memutuskan untuk menjual sebagian sahamnya kepada investor asing dalam hal ini adalah French Danone, dengan jalan melakukan akuisisi saham atau juga disebut dengan aliansi strategis. Akuisisi saham terjadi ketika sebuah perusahaan mengakuisisi saham berhak suara dari perusahaan lain dan kedua perusahaan tersebut tetap beroperasi sebagai entitas hukum yang terpisah, akibatnya muncul perusahaan induk dan perusahaan anak. Akuisisi saham Danone pada PT. Aqua pada 1998 hanya sebesar $40 \%$ dan saat itulah merupakan titik awal perkembangan pesat PT. Aqua, diketahui juga bahwa PT. Aqua mampu menghasilkan laba bersih sebesar Rp 19 miliar atau bertambah $143 \%$ dari tahun sebelumnya.

Informasi keuangan sebagai instrumen data akuntansi diharapkan mampu menggambarkan realita ekonomi. Oleh karena itu pengujian terhadap kandungan informasi akan dapat memengaruhi reaksi pasar atas tingkat pengembalian (return). Salah satu alternatif untuk mengetahui informasi keuangan yang dihasilkan bermanfaat untuk memprediksi harga saham, maka dilakukan analisis rasio keuangan. Menurut Penman dalam Anita Ardiani (2007:3) seperangkat laporan keuangan utama belum dapat memberikan manfaat maksimal bagi pemakai sebelum pemakai menganalisis laporan keuangan tersebut dalam bentuk rasio keuangan. Rasio keuangan menurut Bambang Riyanto (1999:34) dikelompokkan dalam lima jenis 
yaitu: (1) rasio likuiditas, (2) rasio aktivitas, (3) rasio profitabilitas, (4) rasio solvabilitas, dan (5) rasio pasar.

Harga saham adalah nilai suatu saham yang mencerminkan kekayaan perusahaan yang mengeluarkan saham tersebut, di mana perubahan atau fluktuasinya sangat ditentukan oleh kekuatan penawaran dan permintaan yang terjadi di bursa (pasar sekunder). Semakin banyak investor yang ingin membeli atau menyimpan suatu saham, harganya semakin naik, sebaliknya semakin banyak investor yang ingin menjual atau melepaskan suatu saham, harganya semakin bergerak turun. Secara umum, semakin banyak kinerja suatu perusahaan semakin tinggi laba usahanya dan semakin banyak keuntungan yang dapat dinikmati oleh pemegang saham, juga semakin besar kemungkinan harga saham akan naik (Koetin dalam Anita Ardiani 2007:4). Meskipun demikian saham yang memiliki kinerja baik sekalipun, harganya bisa saja turun karena keadaan pasar.

Dalam melakukan prediksi harga saham terdapat pendekatan dasar yaitu analisis fundamental dan analisis teknikal. Secara tradisional analisis fundamental telah memperoleh perhatian yang cukup besar dari para analisis sekuritas. Para praktisi cenderung menyukai penggunaan model yang tidak terlalu rumit, mudah dipahami, dan mendasarkan diri atas informasi akuntansi. Husnan (2003:303) menjelaskan bahwa analisis fundamental mendasarkan pola pikir perilaku harga saham ditentukan oleh perubahan-perubahan variasi perilaku variabel-variabel dasar kinerja perusahaan. Secara ringkas dapat dikatakan bahwa harga saham tersebut ditentukan oleh nilai perusahaan. (Halim dalam Anita Adriani 2007:5) mendukung pernyataan di atas bahwa ide dasar pendekatan ini adalah bahwa harga saham dipengaruhi oleh kinerja perusahaan. Apabila kinerja perusahaan baik maka nilai usaha akan tinggi. Dengan nilai usaha yang tinggi membuat para investor melirik perusahaan tersebut untuk menanamkan modalnya sehingga akan terjadi kenaikan harga saham. Sebaliknya apabila terdapat berita buruk mengenai kinerja perusahaan maka akan menyebabkan penurunan harga saham pada perusahaan tersebut. Atau dapat dikatakan bahwa harga saham merupakan fungsi dari nilai perusahaan. Kinerja perusahaan ini akan menjadi tolok ukur seberapa besar risiko yang akan ditanggung investor. Untuk memastikan kinerja perusahaan tersebut dalam kondisi baik atau buruk dapat dilakukan dengan menggunakan analisis rasio.

Penelitian akan menggunakan alat ukur kinerja keuangan model Z-Score untuk memudahkan dalam menganalisis kinerja keuangan perusahaan yang berpengaruh terhadap harga saham, yang selanjutnya apabila mempunyai pengaruh maka rasiorasio yang terdapat $z$-score tersebut dapat digunakan sebagai alat untuk prediksi. Z-score merupakan suatu bentuk analisis yang dikembangkan pertama kali oleh Edward I. Altman pada 1968 dengan menggunakan metode Multiple Discriminant Analysis (MDA). Dalam penelitiannya tersebut, Altman menyeleksi 22 rasio keuangan. Altman menemukan 5 (lima) rasio keuangan yang dapat dikembangkan untuk menilai kondisi kesehatan keuangan suatu perusahaan. Model Altman dikenal dengan Z-score yaitu skor yang ditentukan dari hitungan standar kali nisbah-nisbah keuangan yang menunjukkan tingkat kemungkinan kebangkrutan perusahaan. 
Namun penelitian ini menggunakan model Z-score untuk menganalisis kesehatan keuangan pada perusahaan yang ditemukan oleh Richard J. Taffler. Z-score model ini berhasil menganalisis kondisi keuangan perusahan yang telah terdaftar di London Stock Exchange dengan sampel 223 perusahaan manufaktur dengan hasil penelitian yang memiliki tingkat keakuratan sebesar 96\%. Dalam penelitiannya tersebut Taffler menggunakan 4 (empat) rasio keuangan yang dinilai sebagai empat kunci profil keuangan pada perusahaan. Analisis diskriminan dilakukan untuk memprediksi kebangkrutan suatu perusahaan dengan menganalisis laporan keuangan suatu perusahaan dua sampai dengan lima tahun sebelum perusahaan tersebut diprediksi bangkrut. Kebangkrutan adalah suatu kondisi di saat perusahaan mengalami ketidakcukupan dana untuk menjalankan usahanya. Kebangkrutan biasanya dihubungkan dengan kesulitan keuangan. Analisis diskriminan bermanfaat bagi perusahaan untuk memperoleh peringatan awal kebangkrutan dan keberlanjutan usahanya. Semakin awal suatu perusahaan memperoleh peringatan kebangkrutan, semakin baik bagi pihak manajemen karena pihak manajemen bisa melakukan perbaikan-perbaikan dan dapat memberikan gambaran dan harapan yang mantap terhadap nilai masa depan perusahaan tersebut.

Dariyus (2004) menganalisis pengaruh kinerja keuangan terhadap harga saham melalui return saham yang menggunakan rumus Holding Period Return Model pada PT. Astra Internasional, Tbk. Kinerja keuangan diukur dengan menggunakan ROA, ROE, Debt to Equity Ratio, dan Book Value. Hasil uji regresi menyimpulkan bahwa secara statistik seluruh variabel bebas yang terdiri dari ROA, ROE, debt to equity ratio, dan book value terhadap return saham cukup besar. Berdasarkan uji Fisher $(F)$ dengan tingkat kepercayaan 95\%, ini berarti hipotesis bahwa seluruh variabel bebas (return on asset, return on equity, debt to equity ratio, dan book value) secara bersama-sama memengaruhi variabel terikat yaitu return saham dapat diterima. Hasil student $t$-test (uji $t$ ) dengan tingkat kepercayaan 95\% menunjukkan bahwa secara parsial return on equity dan debt to equity ratio memengaruhi varibel terikat (return saham). Book value memengaruhi varibel terikat yaitu return saham. Return on asset tidak memengaruhi variable terikat (return saham). Selain itu, Susilawati (2005) dalam jurnal Ilmiah Manajemen meneliti pengaruh enam rasio keuangan (ROA, ROE, PBV, PER, NPM, dan OPM) terhadap perubahan harga saham dengan menggunakan uji statistik multiple linear regression pada 30 perusahaan yang terdaftar di BEJ yang berbasis chemical industry. Hasil penelitian menunjukkan bahwa data dari 1999-2003 rasio keuangan yang digunakan berpengaruh signifikan terhadap harga saham dan variabel independen yang berpengaruh adalah ROE dan PBV.

Berdasarkan latar belakang yang telah diuraikan di atas, maka masalah yang akan diteliti dapat dirumuskan: (1) apakah kinerja keuangan PT. Aqua Golden Mississippi, Tbk. sebelum akuisisi saham berpengaruh terhadap harga saham perusahaan dan (2) apakah kinerja keuangan PT. Aqua Golden Mississippi, Tbk. sesudah akuisisi saham berpengaruh terhadap harga saham perusahaan. 


\section{METODE PENELITIAN}

Metode penelitian yang dipergunakan dalam penelitian ini adalah metode penelitian kuantitatif. Sebagai alat untuk menganalisis digunakan analisis $z$-score model Taffler untuk mengetahui kinerja keuangan perusahaan. Sedangkan analisis regresi linear sederhana digunakan oleh peneliti untuk mengetahui pengaruh kinerja keuangan terhadap harga saham perusahaan. Populasi dan sampel yang digunakan dalam penelitian ini adalah laporan keuangan PT. Aqua Golden Mississippi, Tbk. tahun buku 1997-2007. Sedangkan, sampel yang digunakan adalah laporan keuangan berupa neraca dan laporan laba rugi. Selain laporan keuangan, diambil juga data tentang harga saham yang ada di pasar. Teknik sampling yang digunakan adalah purposive sampling yaitu teknik sampling yang digunakan apabila peneliti mempunyai pertimbangan-pertimbangan tertentu dalam pengambilan sampel atau penentuan sampel untuk tujuan tertentu. Adapun kriteria dari pengambilan sampel pada penelitian ini yaitu: (1) laporan keuangan perusahaan yaitu neraca dan laporan laba rugi PT. Aqua Golden Missisippi, Tbk. sebelum akuisisi saham dan setelah akuisisi saham yang telah dipublikasikan dan diaudit oleh akuntan publik dan (2) harga saham perusahaan yang tercatat di BEI dari 1997-2007. Adapun sampel dari penelitian ini adalah laporan keuangan yang terdiri dari neraca dan laporan laba rugi dengan tahun buku 1997-2007 dikarenakan angka tahun tersebut menunjukkan aktivitas perusahaan sebelum akuisisi dan setelah akuisisi serta harga saham perusahaan yang tercatat di BEI dengan angka tahun yang sama. Variabel yang digunakan dalam penelitian ini dapat dikelompokkan sebagai berikut:

(1) Variabel Dependen: harga saham PT. Aqua Golden Mississippi, Tbk. sebelum akuisisi $\left(\mathrm{Y}_{1}\right)$ dan harga saham PT. Aqua Golden Mississippi, Tbk. sesudah akuisisi $\left(\mathrm{Y}_{2}\right)$.

(2) Variabel Independen: kinerja keuangan PT. Aqua Golden Mississippi, Tbk. sebelum akuisisi saham oleh Danone $\left(\mathrm{X}_{1}\right)$ dan kinerja keuangan PT. Aqua Golden Mississippi, Tbk. setelah akuisisi saham oleh Danone $\left(\mathrm{X}_{2}\right)$.

Analisis data menggunakan regresi sederhana yang diolah dengan menggunakan program SPSS.

\section{HASIL DAN PEMBAHASAN \\ Hasil}

Analisis data dalam penelitian ini adalah analisis kinerja keuangan PT. Aqua Golden Mississippi, Tbk. dengan data analisis berupa neraca dan laporan laba rugi yang diukur dengan menggunakan rasio keuangan yang terdapat dalam z-score model Taffler pada periode sebelum dan setelah akuisisi. Setelah itu kinerja keuangan yang dihasilkan dari zeta score pada periode sebelum dan setelah akuisisi akan dilihat pengaruhnya terhadap harga saham perusahaan. Kemudian dilakukan pengujian terhadap analisis regresi dengan menggunakan program SPSS versi 16. Melalui pengujian tersebut akan didapatkan persamaan garis regresi dari data penelitian serta gambaran pengaruh variabel bebas terhadap variabel terikat. 
Hasil pengujian regresi dari penelitian ini adalah: Uji regresi sebelum akuisisi diperoleh persamaan regresi sebagai berikut:

$$
\mathrm{Y}_{1}=6946.972-261.975 \mathrm{X}_{1}+e \ldots \ldots \ldots \ldots \ldots \ldots \text { (a) }
$$

Uji Regresi Sebelum Akuisisi diperoleh persamaan regresi sebagai berikut:

$$
\mathrm{Y} 2=13492.283+380.620 \mathrm{X} 2+e
$$

Kemudian dilakukan uji normalitas bertujuan untuk menguji apakah dalam model regresi, variabel pengganggu atau residual memiliki distribusi normal. Dari hasil pengolahan statistik diperoleh grafik pengujian normalitas, yaitu grafik histogram dan gambar plot. Dari grafik akan disimpulkan apakah model regresi merupakan model yang normal. Dari hasil perhitungan program SPSS maka dapat disimpulkan bahwa model regresi dalam penelitian ini memenuhi asumsi normalitas. Pengujian signifikansi pengaruh variabel bebas terhadap variabel terikat secara parsial dilakukan dengan melakukan uji parsial (uji $t$ ). Hipotesis yang digunakan adalah sebagai berikut: $\mathrm{H}_{0}: \mathrm{b} 1: \mathrm{b} 2=0$, artinya secara individual tidak ada pengaruh yang signifikan dari variabel bebas terhadap variabel terikat. $\mathrm{H}_{1}$ : b1: $\mathrm{b} 2 \neq 0$, artinya secara individual ada pengaruh yang signifikan dari variabel bebas terhadap variabel terikat. $\mathrm{H}_{2}: \mathrm{b} 1: \mathrm{b} 2 \neq 0$, artinya secara individual ada pengaruh yang signifikan dari variabel bebas terhadap variabel terikat.

Pengujian ini menggunakan Level of significance sebesar 95\% dengan ó sebesar 5\%. Apabila $t_{\text {hitung }}<t_{\text {tabel }}$, maka $\mathrm{H}_{\mathrm{o}}$ diterima dan $\mathrm{H}_{\mathrm{a}}$ ditolak, artinya variabel bebas tidak berpengaruh signifikan terhadap variabel terikat dan sebaliknya apabila $t_{\text {hitung }}>$ $t_{\text {tabel}}$, maka variabel bebas berpengaruh signifikan terhadap variabel terikat.

a. Uji t Sebelum Akuisisi

Dari tabel di atas tersebut didapatkan nilai $t_{\text {hitung variabel bebas kinerja keuangan }}$ sebelum akuisisi sebesar -6.589. Dengan membandingkan antara $t_{\text {hitung }}$ dengan $\mathrm{t}_{\text {tabel}}$, maka dapat disimpulkan bahwa nilai $\mathrm{t}_{\text {hitung }}$ sebelum akuisisi sebesar -6.589 lebih besar dari $t_{\text {tabel }}$ sebesar 2.571, maka menolak hipotesis nol $\left(\mathrm{H}_{\mathrm{o}}\right)$ menerima hipotesis alternatif $\left(\mathrm{H}_{1}\right)$, artinya variabel nilai $z$-score yaitu yang menunjukkan kinerja keuangan tersebut berpengaruh secara signifikan terhadap perubahan harga saham pada PT. Aqua Golden Mississippi, Tbk. tetapi hubungan yang terjadi adalah negatif.

b. Uji t Sesudah Akuisisi

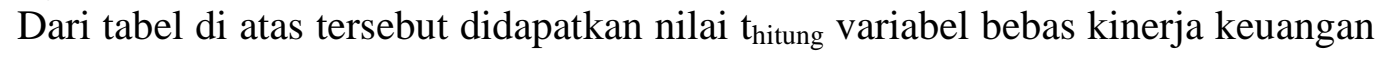
sesudah akuisisi adalah 1.827. Dengan membandingkan antara $t_{\text {hitung }}$ dengan $t_{\text {tabel }}$, maka dapat disimpulkan bahwa nilai $\mathrm{t}_{\text {hitung }}$ sesudah akuisisi sebesar 1.827 lebih kecil dari $\mathrm{t}_{\text {tabel }}$ sebesar 2.447, maka menerima hipotesis nol $\left(\mathrm{H}_{\mathrm{o}}\right)$ menolak hipotesis alternatif $\left(\mathrm{H}_{2}\right)$, artinya variabel nilai $z$-score yaitu yang menunjukkan kinerja keuangan tersebut tidak berpengaruh secara signifikan terhadap perubahan harga saham pada PT. Aqua Golden Mississippi, Tbk. 
Kesimpulan terhadap uji parsial juga dapat dilihat dari nilai probabilitas. Jika probabilitas $>5 \%(0,05)$ maka variabel bebas tidak berpengaruh signifikan terhadap variabel terikat dan sebaliknya jika probabilitas $<5 \%(0,05)$ maka variabel bebas berpengaruh signifikan. Dari hasil perhitungan di atas, dapat dilihat bahwa variabel kinerja keuangan sebelum akuisisi saham menunjukan nilai probabilitas lebih kecil dari 0,05 yaitu sebesar 0,007, artinya variabel bebas kinerja keuangan sebelum akuisisi saham berpengaruh signifikan secara parsial terhadap harga saham pada PT. Aqua Golden Mississippi, Tbk. dengan nilai $t_{\text {hitung }}$ sebesar -6.589 dengan hubungan yang negatif. Sedangkan variabel kinerja keuangan sesudah akuisisi saham menunjukan nilai probabilitas lebih besar dari 0,05 yaitu sebesar 0,142 , artinya variabel bebas kinerja keuangan sesudah akuisisi saham tidak berpengaruh signifikan secara parsial terhadap harga saham pada PT. Aqua Golden Mississippi, Tbk. dengan nilai $t_{\text {hitung }}$ sebesar 1.827 dengan hubungan positif.

Berdasarkan analisis model regresi, setelah dilakukan uji $t$ maka dapat dibuat kesimpulan terhadap hipotesis penelitian yang telah dibuat sebelumnya, di mana hipotesis tersebut dibuktikan sebagai berikut: (1) hipotesis pertama adalah kinerja keuangan sebelum akuisisi saham secara parsial berpengaruh secara signifikan terhadap variabel terikat penelitian yaitu harga saham pada PT. Aqua Golden Mississippi, Tbk. Hipotesis ini terbukti karena berdasarkan uji $t$, dinyatakan bahwa kinerja keuangan sebelum akuisisi saham signifikan terhadap harga saham pada PT. Aqua Golden Mississippi, Tbk. dengan nilai $t_{\text {hitung }}$ sebelum akuisisi sebesar -6.589 lebih besar dari $t_{\text {tabel }}$ sebesar 2.571 tetapi memiliki hubungan negatif, (2) hipotesis kedua adalah kinerja keuangan PT. Aqua Golden Mississippi, Tbk. sesudah akuisisi saham oleh Danone secara parsial tidak berpengaruh signifikan terhadap variabel terikat penelitian yaitu harga saham pada PT. Aqua Golden Mississippi, Tbk. Setelah dilakukan pengujian secara parsial maka hipotesis tersebut terbukti karena berdasarkan hasil uji $t$ dinyatakan bahwa kinerja keuangan sesudah akuisisi saham sebagai variabel bebas tidak berpengaruh secara signifikan terhadap harga saham pada PT. Aqua Golden Mississippi, Tbk. dengan nilai thitung sesudah akuisisi sebesar 1.827 lebih kecil dari $t_{\text {tabel }}$ sebesar 2.447 dengan hubungan positif.

\section{PEMBAHASAN}

Hasil pengujian menunjukkan bahwa pada model regresi telah berdistribusi normal sehingga hasil dari pengujian tersebut dapat diaplikasikan lebih lanjut. Model persamaan regresi menunjukkan hasil bahwa salah satu variabel independen atau bebas yaitu kinerja keuangan sebelum akuisisi saham signifikan untuk uji parsial (uji $t$ ), sehingga dapat disimpulkan bahwa variabel tersebut berpengaruh signifikan secara parsial terhadap harga saham pada PT. Aqua Golden Mississippi, Tbk., sedangkan variabel yang lain yaitu kinerja keuangan sesudah akuisisi saham tidak berpengaruh secara signifikan: (a) pengaruh kinerja keuangan sebelum akuisisi saham oleh Danone terhadap harga saham pada PT. Aqua Golden Mississippi, Tbk. adalah kinerja keuangan sebelum akuisisi saham oleh Danone terhadap harga saham pada PT. Aqua Golden Mississippi, Tbk. menunjukkan bahwa kinerja keuangan PT. Aqua 
Golden Mississippi, Tbk. sebelum diakuisisi saham oleh pihak Danone memengaruhi harga saham perusahaan. Apabila kinerja keuangan perusahaan mengalami peningkatan, maka harga saham menunjukkan keadaan yang sama. Tetapi hubungan yang terjadi adalah hubungan yang negatif. Hal ini dikarenakan terdapat faktor-faktor lain yang memengaruhi harga saham pada PT. Aqua Golden Mississippi, Tbk. Salah satu faktornya adalah saham perusahaan penguasa lebih dari 40 persen pasar air minum dalam kemasan ini tidak likuid di bursa, volume dan frekuensi transaksinya secara terus-menerus mengalami penurunan. Selama periode Januari-Juli 2001, volume perdagangannya hanya 50 ribu lembar saham dengan frekuensi 52 transaksi. Sedikitnya perdagangan saham membuat harga saham cenderung untuk tidak berubah. Kinerja keuangan sebelum akuisisi saham berpengaruh secara signifikan terhadap harga saham pada perusahaan. Hal ini menunjukkan bahwa peningkatan kinerja keuangan tidak akan dengan begitu saja diikuti oleh kenaikan harga saham perusahaan pada PT. Aqua Golden Mississippi, Tbk. Keadaan tersebut terjadi pada saat sebelum perusahaan diakuisisi oleh Danone. Riset yang dilakukan oleh Asep Rohimat dan Dita Tania Maharani (MarkPlus \& Co) dalam reportase Dede Suryadi dan Eva Martha Rahayu yang ditulis oleh Kusnan M. Djawahir (www.swa.co.id) menghasilkan kesimpulan yang hampir sama dengan penelitian ini. Artikel yang ditulis berdasarkan riset tersebut menyebutkan bahwa kinerja keuangan yang dihasilkan dengan angka EVA positif, harga sahamnya akan terkatrol atau dengan kata lain akan meningkat, sehingga shareholders bertambah kaya. Selain itu, perusahaan menjadi lebih mudah mendapatkan dana, karena investor percaya perusahaan tersebut mampu mendatangkan nilai bagi perusahaan. Pernyataan tersebut juga didukung dengan hasil tesis dalam blog yang ditulis oleh Dwi Setyani Rahardjo menunjukkan bahwa pada periode 1996 sampai dengan 1999 EVA yang dihasilkan oleh PT. Aqua Golden Mississippi, Tbk. memberikan nilai yang negatif salah satu akibat dari pembengkakan beban pokok penjualan sehingga laba yang diterima mengalami penurunan dan harga saham Aqua juga mengalami hal yang serupa, kondisi tersebut saat perusahaan sebelum diakuisisi. Penyebabnya adalah adanya tingkat suku bunga bank yang tinggi akibat gelombang krisis ekonomi dan risiko saham perusahaan relatif terhadap indeks pasar jauh di bawah angka 1 (yaitu 1996 = 1,$14 ; 1997=0,44 ; 1998=0,39 ; 1999=0,16$ ).

Pengaruh kinerja keuangan sesudah akuisisi saham oleh Danone terhadap harga saham pada PT. Aqua Golden Mississippi, Tbk. adalah kinerja keuangan PT. Aqua Golden Mississippi, Tbk. setelah akuisisi tidak berpengaruh secara signifikan terhadap harga saham perusahaannya. Hal ini diartikan bahwa semakin baik atau meningkatnya kinerja keuangan perusahaan setelah akuisisi, maka tidak mengkibatkan naiknya harga saham pada PT. Aqua Golden Mississippi, Tbk. Dalam hal ini kinerja keuangan suatu perusahaan yang baik tidak memengaruhi kenaikan terhadap harga saham perusahaan yang bersangkutan. Karena terdapat faktor-faktor eksternal pada perusahaan, sehingga para investor tidak hanya melihat dari sisi fundamental atau kinerja keuangan perusahaan saja. Hal ini dapat dilihat dari kinerja keuangan PT. Aqua Golden Mississippi, Tbk. setelah diakuisisi dari 2002-2007 
berturut-turut yakni sebesar 93.33\%, 147.63\%, 150.98\%, 176.38\%, 192.28\%. Dengan peningkatan kinerja keuangan tersebut tidak mendorong para investor untuk melakukan transaksi di bursa terhadap saham PT. Aqua Golden Mississippi, Tbk., karena pada saat itu investor menilai bahwa harga saham PT. Aqua Golden Mississippi, Tbk. harganya terlampau tinggi apabila dibandingkan dengan harga saham perusahaan sejenis dan juga keinginan perusahaan untuk segera menjadi perusahaan tertutup atau go private, sehingga para investor lebih cenderung untuk menginvestasikan dananya dalam bentuk lain atau pada perusahaan lain sejenis yang harga sahamnya tidak terlampau tinggi dan likuid di bursa. Untuk menyimpulkan keterkaitan antara kinerja keuangan dan saham di pasar modal Indonesia, diperlukan studi lebih lanjut. Terlebih, di pasar saham yang kurang efektif seperti di Indonesia, keputusan membeli saham tak semata-semata didasarkan pada faktor fundamental. Aksi spekulasi dan goreng- menggoreng saham pun kerap mewarnai bursa saham.

\section{SIMPULAN DAN SARAN}

\section{Simpulan}

Berdasarkan pengujian secara parsial dengan menggunakan uji parsial (uji $t$ ) terhadap variabel independen, maka dapat disimpulkan sebagai berikut: (1) variabel independen kinerja keuangan sebelum akuisisi saham $\left(\mathrm{X}_{1}\right)$ berpengaruh secara signifikan terhadap harga saham pada PT. Aqua Golden Mississippi, Tbk. Hubungan antara kinerja keuangan perusahaan sebelum akuisisi terhadap harga saham adalah hubungan negatif, artinya apabila kinerja keuangan perusahaan mengalami peningkatan maka kondisi tersebut tidak begitu saja diikuti oleh harga saham PT. Aqua Golden Mississippi, Tbk. pada saat perusahaan belum diakuisisi oleh Danone. Hal ini dikarenakan terdapat faktor-faktor lain yang memengaruhi harga saham pada PT. Aqua Golden Mississippi, Tbk. Salah satu faktornya adalah saham perusahaan penguasa lebih dari 40 persen pasar air minum dalam kemasan ini tidak likuid di bursa, volume dan frekuensi transaksinya secara terus-menerus mengalami penurunan. Selama periode Januari-Juli 2001, volume perdagangannya hanya 50 ribu lembar saham dengan frekuensi 52 transaksi. Sedikitnya perdagangan saham membuat harga saham cenderung untuk tidak berubah.

Variabel independen kinerja keuangan setelah akuisisi saham $\left(\mathrm{X}_{2}\right)$, hasil pengujian secara parsial menunjukkan bahwa variabel tersebut tidak berpengaruh secara sigifikan terhadap variabel dependen yaitu harga saham pada PT. Aqua Golden Mississippi, Tbk. dan mempunyai hubungan yang positif artinya apabila kinerja perusahaan sesudah akuisisi saham yang dihitung dengan Zeta Score nilainya meningkat, maka harga saham PT. Aqua Golden Mississippi, Tbk. tidak mengalami peningkatan. 


\section{Saran}

Dari hasil yang telah dianalisis dalam penelitian ini dan manfaat yang telah diberikan maka saran yang dapat disampaikan adalah jumlah perusahaan yang digunakan sebagai objek penelitian, menambahkan atau menggunakan alat ukur kinerja keuangan lain untuk proses pembanding terhadap hasil yang telah dicapai. 


\section{DAFTAR PUSTAKA}

Adnan, Akhyar Muhammad dan Kurniasih, Eka.2000. Analisis Tingkat Kesehatan Perusahaan untuk Memprediksi Potensi Kebangkrutan dengan Pendekatan Altman (studi pada perusahaan perbankan dan non perbankan yang terdaftar di BEJ). JAAI Vol. 4, No. 2 hal 131-151.

Agustiono dan Devi Ika Puspitosari. 2004. Analisis Z-Score dalam Memprediksi

Kebangkrutan Bank Go Publik di BEJ. Jurnal Eksekutif, Vol.1, No.1.

Algifari. 2000. Analisis Regresi: Teori, Kasus, dan Solusi. Yogyakarta: Liberty.

Altman. I Edward. 1991. Corporate Financial Distress and Bankruptcy. Edisi kedua. New York: John Wiley and Sains Inc.

Altman, I. Edward. 1968. The Journal of Finance "Finance Ratios, Discriminant Analysis and The Prediction of Corporate Bankruptcy". (Online), diakses tanggal 14 Maret 2009.

Ardiani, Anita. 2007. Analisis Pengaruh Kinrja Keuangan terhadap Perubahan Harga Saham pada Perusahaan Perbankan di Bursa Efek Jakarta (BEJ.(Online) diakses tanggal 18 April 2009.

Azizudin, Data Agis. 2003. Analisis Pengaruh Merger dan Akuisisi terhadap Kinerja Perusahaan (Studi Empiris pada Perusahaan Manufaktur yang terdaftar di BEJ), (Online), diakses tanggal 18 April 2009.

BEI. Indonesia Capital Market Directory PT Aqua Golden Mississippi, Tbk tahun 1997-2007.

Dariyus. 2004. Pengaruh kinerja Keuangan terhadap Harga Saham pada PT Astra Internasional, Tbk. (Online), (http://laptunilapp-gdl-s2-2006-dariyus-5722004_ts-1//pdf), diakses tanggal 18 April 2009.

Djawahir, M. Kusnan. 2003. Sulitnya Menciptakan Nilai Tambah bagi Shareholders.(Online) diakses tanggal 4 Februari 2009.

George, Bancrort Gordon. 1988. Match and Statistics for Accounting and Business Studies. England: Mc Graw-Hill Book Company (UK) Limited.

Ghozali, Imam. 2001. Aplikasi Analisis Multivariate dengan Program SPSS. Semarang: Badan Penerbit UNDIP.

Gujarati, Damodar. 2003. Basic Econometrics. New York: Mc Graw-Hill

Husnan, Suad. 2003. Dasar-Dasar Teori Portofolio dan Analisis Sekuritas. Yogyakarta: BPFE-UGM.

Ikatan Akuntan Indonesia. 2004. Pernyataan Standar Akuntansi Keuangan. Jakarta: Salemba Empat.

Machfoed, M. 1994. Financial Ratio Analysis and The Earning Change in Indonesia, kelola, No. 114-147.

Malhotra, K. Naresh. 2005. Riset Pemasaran: Pendekatan Terapan. Jakarta: Indeks Munawir. 2001. Analisis Laporan Keuangan. Yogyakarta: Liberty.

Rahardjo, S. Dwi. 2009. Closing Case PT Aqua Group. (Online) diakses tanggal 31 Agustus 2009 
Riyanto, Bambang. 1999. Dasar-Dasar Pembelanjaan Perusahaan. Yogyakarta: BPFE UGM.

Santoso, Singgih. 2001. SPSS Statistik Non Parametik. Jakarta: Elex Media Computindo.

Sawitri, Peni. 2002. Prediksi Tingkat Kesehatan Preusan Asuransi Jiwa Termasuk Kemungkinan Kebangkrutan dengan Rasio-Rasio Keuangan. Jurnal Manajemen No. 2 , jilid 7.

Sudarsanam, P. S. 1995. The Essence of Merger \& Akuisisi. Yoyakarta: Andi

Sugiyono.2008. Metode Penelitian Kuantitatif Kualitas dan R\&D. Bandung; Alfabeta.

Susilawati, Dwi Karya Christine. 2005. Pengaruh Rasio keuangan terhadap harga Saham pada Perusahaan Manufaktur. Jurnal Ilmiah Manajemen Vol.5, No.2.

Taffler, J. Richard. 2007. Tweenty-Five the Taffler Z-Score Model: does it really have predictive ability? (Online), version 8.0: June 14, 2007, (http://journalvineet.agarwal @ cranfield//pdf), diakses tanggal 5 September 2008.

Tim Penyusun. 2006. Panduan Penulisan dan Penilaian Skripsi. Surabaya: UNESA

Wibisono, Darmawan. 2006. Manajemen Kinerja: Konsep, Desain, dan Tehnik Meningkatkan Daya Saing Perusahaan. Jakarta: Erlangga.

Wild, J. John, K. R. Subramanyam, Robert F. Hasley. 2005. Financial Statment Análisis. Analisis Laporan Keuangan. Edisi 8. Jakarta: Salemba Empat.

www.aqua.com. Financial Highlight Aqua 1997 dan Prospectus Aqua 2003. (Online) diakses tanggal 30 April 2009. 